\title{
Detection Of Extended Spectrum $B$-Lactamase (ESBL) Gene Patterns Of Enterobacteriaceae In Broiler Chicken Meat Sold In Traditional Markets In The East Surabaya
}

\author{
Binti Mu'arofah', Radita Yuniar Arizandy², Budi Utomo ${ }^{3}$, K. Kuntaman 2,4* \\ ${ }^{1}$ Institut Ilmu Kesehatan Bhakti Wiyata Kediri, Basic Medical Science Master Program, Faculty of \\ Medicine, Airlangga University, Surabaya \\ 2 Institute of Tropical Disease, Airlangga University, Surabaya \\ 3 Departement of Public Health, Faculty of Medicine, Airlangga University, Surabaya \\ 4 Departement of Microbiology, Faculty of Medicine, Airlangga University, RSUD Dr. Soetomo, Surabaya \\ Corresponding author: K. Kuntaman,Faculty of Medicine Universitas Airlangga, \\ kuntaman@fk.unair.ac.id
}

\begin{abstract}
Chicken meat is one of the livestock commodities that has equivalent nutritional value compared to other meat. Several types of microbes found in food such as Enterobacteriaceae (Escherichia coli, Shigella spp, Salmonella spp, Enterobacter spp, Klebsiella spp, and Proteus spp) and other pathogenic microbes easily contaminate chicken meat. Microbial contamination of food comes from the soil, air, water, dust, digestive tract, the touch of human hands, animal beats such as cockroaches and flies, ESBL producing bacteria are one of them. Enterobacteriaceae can survive on the surface and water for a long time. In the process of separating viscera from broiler chicken meat, contamination can occur from broiler organ visceral. The three main genes of the ESBL encoder are TEM, SHV, and CTX-M. This study was to analyze the pattern of colonization of ESBL-producing bacteria and ESBL gene patterns in broiler chicken meat. Random sampling was chosen for collecting broiler chicken meat. One hundred portions of broiler chicken meat were taken from the Traditional Market in East Surabaya. This study was an observational analytic study with a cross-sectional approach. Bacteria were growth in TSB media then screened for ESBL production on McConkey Agar with Cefotaxime $2 \mathrm{ug} / \mathrm{ml}$. Afterward, continue for phenotypic screening using Double Disk Synergy Test (DDST). Finally, the detection of ESBL gene by using PCR. ESBL-producing bacteria were found in $33(33 \%)$ broiler chicken samples with thirty positive $E$. coli, and three positive samples of Pseudomonas aeruginosa. Positive gene detection in SHV genes (1\%), TEM genes (18\%) and CTX-M genes (24\%). ESBL producing bacteria have spread in broiler chicken meat $(33 \%)$ sold in traditional markets, including Escherichia coli and Pseudomonas aeruginosa.
\end{abstract}

Keywords: Enterobacteriaceae, ESBL, Broiler Chicken Meat

Received December, 25, 2019; Revised January 24, 2020; Accepted February 15, 2020

(7) (D) STRADA Jurnal Ilmiah Kesehatan, its website, and the articles published there in are licensed under a Creative Commons Attribution-ShareAlike 4.0 International License. 


\section{STRADA Jurnal Ilmiah Kesehatan}

DOI: $10.30994 /$ sjik.v9i1.264

ISSN: 2252-3847 (print); 2614-350X (online)

Vol.9 No.1. May 2020. Page.12-19

\section{INTRODUCTION}

Chicken meat is one of the livestock commodities with a nutritional value equivalent to other meat nutritional values (Soegiyono, 2013). The need for broiler chicken meat in Indonesia tends to increase by $10 \%$ every year. In 2017, the consumption amounting to $5.68 \mathrm{~kg}$ per capita/ year increased 573 grams (11.2\%) compared to the previous year's expenditure. This increase in demand is in line with Indonesia's growing economic situation. The culinary-based broiler meat increased from roadside stalls to shopping centers, which make consumption of chicken meat increased during 2013-2017. Broiler meat production in 2017 reached 2.14 million tons, an increase of 97 thousand tons (4.75\%) from 2016, which was only 2.04 million tons.

Food consumption of chicken meat containing antibiotic residues will cause health problems. The residual hazards of veterinary drugs can be direct short-term hazards such as allergies, digestive disorders, skin disorders, anaphylaxis and hypersensitivity, and indirect long-term hazards such as microbiological resistance, carcinogenic, mutagenic, teratogenic and reproductive disorders (Ruegg et al., 2013). Various microorganisms from the surrounding environment easily contaminate chicken meat. Some types of microbes found in food are Enterobacteriaceae (Escherichia coli, Shigella spp, Salmonella spp, Enterobacter spp, Klebsiella spp, and Proteus spp.) and other pathogenic microbes. Microbial contamination in food is the result of direct or indirect contamination, with sources of microbial pollution such as soil, air, water, dust, digestive tract, human and animal respiration such as cockroaches and flies (Widyawati P. et al., 2013). Foods derived from animals, especially from poultry, are the main source of infection from the effects of contamination. Enterobacteriaceae is a disease-causing agent in foods such as broiler chicken meat (Tham et al., 2012; Gines et al., 2015).

Enterobacteriaceae can survive on the surface and water for a long time. Contamination can occur during the process of separating viscera (Koga et al., 2015; Paholewicz et al., 2015). These bacteria can be transmitted from chicken to one another during extraction of feathers, separation of viscera and washing in water (Gregova et al., 2012). Extended spectrum $\beta$-lactamase and Enterobacteriaceae in broiler chickens when slaughtered. Most of the isolates identified were Escherichia coli, Enterobacter aerogenes and Proteus mirabilis. In Germany, fresh chicken is the source of the spread of Enterobacteriaceae which is carried during the maintenance of feeding and when cutting (Reich et al., 2013).

Extended Spectrum of $\beta$-lactamase (ESBL) is an $\beta$-lactamase capable of causing bacterial resistance to penicillin; first, second, and third generation cephalosporins; and aztreonam (but not to cefamycin and carbapenem) by hydrolysis of these antibiotics, where enzyme activity can inhibited by $\beta$-lactamase inhibitors such as clavulanic acid (Paterson and Bonomo, 2005).

The three main ESBL coding genes are TEM, SHV, and CTX-M (Johns et al., 2012). These three genes produce ESBL in hydrolyzing $\beta$-lactam antibiotics (Sana et al., 2011). The ESBL gene is located in a plasmid, which can be easily disseminated between, and intra bacterial species (Santos et al., 2013). Although the AmpC chromosome gene exists in several Enterobacter aerogenes and E. coli, the plasmid-bound types can be transferred between bacteria, and it can cause an overall distribution of antimicrobial resistance. Carrier bacteria are not pathogenic, but can cause opportunistic infections in immunosuppressive humans, because E. coli is an ESBL producer (Reich et al., 2013).

The phenotypic test for ESBL detection is only used to confirm these bacterial strains including ESBL producers or not. However, it cannot detect the ESBL subtype, which can 


\section{STRADA Jurnal Ilmiah Kesehatan}

DOI: $10.30994 /$ sjik.v9i1.264

ISSN: 2252-3847 (print); 2614-350X (online)

Vol.9 No.1. May 2020. Page.12-19

only be done by molecular techniques, one of which is the PCR (Polymerase Chain Reactions) technique (Sharma et al., 2010).

\section{METHODS}

\section{Sampling}

This study is an observational analytic-comparative study with cross sectional design. Samples are taken randomly at each traditional market location. A sample of 100 servings of broiler chicken is taken from traditional markets in the East Surabaya. Every traditional market, one chance is taken for one sample of broiler chicken.

\section{Procedure for Identifying ESBL Producing Bacteria}

Broiler chicken samples are carried out according to methods that are routinely carried out by several researchers (Arslan and Eyi, 2011; Nadine et al., 2012; Stuart et al., 2012; Tekiner and Özpınar, 2016) with some modification. Broiler chicken meat is cut into small pieces using sterile scissors and placed in a sterile plastic bottle, with a weight of 10 grams of meat. The chicken meat is grinded using sterile stamper then added $20 \mathrm{ml}$ of TSB (Trypticase Soy Broth) media, 3 minutes cortex until homogeneous and incubated at $37^{\circ} \mathrm{C}$ for 4 hours. Afterward, $50 \mathrm{ul}$ was taken and planted scattered to the entire surface of McConkey media containing cefotaxime $2 \mathrm{ug} / \mathrm{ml}$, incubated at $37^{\circ} \mathrm{C}$ for 24 hours. The growing colonies thought to be ESBL producing bacteria, were isolated and tested with DDST and bacterial species identification (Nakayama, 2015).

\section{Phenotypic Double Disk Synergy Test (DDST) as Confirmation Test}

The bacterial suspension was taken from colonies grown in McConkey containing cefotaxime $2 \mu \mathrm{g} / \mathrm{ml}$. Then, inserted into a tube containing $5 \mathrm{ml}$ of Trypticase Soy Broth (TSB), turbidity was calibrated with the McFarland 0.5 standard. Afterward, it was spread on Muller Hinton until evenly distributed and waited for 15 minutes. The antibiotic Amoxiklav (AMC) placed right in the middle and the Ceftazidime, Cefotaxime, Ceftriaxone, Astreonam placed with a distance of $20 \mathrm{~mm}$ (between the center point of the disc to the center of AMC discs). Then, incubated at $37^{\circ} \mathrm{C}$ for 24 hours. Observation on the widening of the inhibitory zone on CRO, CAZ, CTX and ATZ discs around the edge of the disk facing AMC, against amoxiclav (AMC) disks placed in the center, indicating the production of ESBL enzymes. The widening of the inhibitory zone varies and is called the key hole effect (Shaikh et al, 2016).

\section{Biochemical Test of ESBL Producing Bacteria}

Biochemical tests were carried out to diagnose the ESBL-producing bacterial species found. The tests were the TSIA Test, Indol, MR (Methyl Red) Test, VP Test (Voges Proskauer), Citrate Test, and Motility Test. Planting on the media was carried out and identification of the results according to diagnostic guidelines (Tille P.M. et al., 2014).

\section{Genotypic Confirmation (PCR)}

Detection of SHV, TEM and CTX-M genes Multiple PCR is by using primers from each of these genes. The PCR process begins with DNA extraction, SHV, TEM and CTX-M gene amplification, and electrophoresis. DNA extraction was carried out according to the procedure described in Bali et al. (2010). The extraction results were tested for purity using a spectrophotometer at a wavelength ratio of $260 \mathrm{~nm}$ and $280 \mathrm{~nm}$. DNA samples were measured for absorbance. The optical density ratio (OD) 260/280 is calculated, if the result is 1.8-2, the DNA purity level produced is high and can be used further (Herveg and Regaert, 2005; Barbas et al., 2007). PCR of SHV is run with temperature between $60^{\circ} \mathrm{C}$ $96^{\circ} \mathrm{C}$ for 10 minutes, TEM between $72^{\circ} \mathrm{C}-96^{\circ} \mathrm{C}$ for 10 minutes, and CTX-M between $72^{\circ} \mathrm{C}-94^{\circ} \mathrm{C}$ for 7 minutes. The isolates of ESBL positive Enterobacteriaceae bacteria 


\section{STRADA Jurnal Ilmiah Kesehatan}

DOI: $10.30994 /$ sjik.v9i1.264

ISSN: 2252-3847 (print); 2614-350X (online)

Vol.9 No.1. May 2020. Page.12-19

carrying SHV, TEM and CTX-M genes, from observed DNA bands were included in the tabulation. (Sudarwanto et al., 2015; Lukman et al., 2016).

\section{Data analysis}

Data collected from the research results are presented in the form of a table then data analysis is performed.

\section{RESULTS}

The study was conducted from March 18 to May 29, 2019 at the Clinical Microbiology Installation of Dr. RSU Soetomo Surabaya and the Institute of Tropical Disease, Airlangga University. Of the 100 broiler chicken meat samples, 33 (33\%) positive samples contained ESBL producing bacteria, which consisted of 30 (30\%) samples containing Escherichia coli and 3 (3\%) samples containing Pseudomonas aeruginosa. Analysis of ESBL genes in 33 positive samples shows there is one or more ESBL genes, with the the total number of ESBL genes was 18 TEM, 1 SHV and 24 CTX-M. The presence of a combined gene in each bacterium was found in 15 isolates, which contained a combination of the TEM and CTX-M genes (Table 1).

Table 1.v Distribution of ESBL genes in ESBL producing bacteria contaminated with broiler chicken meat sold in traditional markets in the East Surabaya city.

\begin{tabular}{|c|c|c|c|c|}
\hline \multirow[t]{2}{*}{ Gene name } & \multicolumn{2}{|c|}{ Broiler chicken meat $(\mathrm{n}=100)$} & \multirow[b]{2}{*}{$\begin{array}{l}\text { Total } \\
\text { ESBL }\end{array}$} & \multirow[b]{2}{*}{ Total gene } \\
\hline & Escherichia coli & $\begin{array}{c}\text { Pseudomonas } \\
\text { aeruginosa }\end{array}$ & & \\
\hline ESBL Pos & $30(30 \%)$ & $3(3 \%)$ & 33 & \\
\hline ESBL Neg & - & - & 67 & \\
\hline Total & & & 100 & \\
\hline SHV & 1 & - & & 1 \\
\hline TEM & 18 & - & & 18 \\
\hline CTX-M & 23 & 1 & & 24 \\
\hline Total gene & 42 & 1 & & 43 \\
\hline
\end{tabular}

Description: Examination of ESBL genes namely SHV, TEM and CTX-M was carried out by PCR of 33 broiler chicken meat.

\section{DISCUSSION}

ESBL producing bacteria in broiler chickens sold in traditional markets in Surabaya The Eastern region contains $30 \%$ Escherichia coli 30 and 3\% Pseudomonas aeruginosa 3 (Table 1). Research in Netherland on the broad spectrum of beta-lactamase-producing bacteria (ESBL) in animals consumed by humans and contamination of meat can contribute to the increased incidence of infection with ESBL-producing bacteria in humans. Transmission of ESBL genes, plasmids and Escherichia coli isolates from poultry to humans, most likely through the food chain transmission of ESBL genes, plasmids and Escherichia coli isolates from birds to humans (Leverstein et al., 2011).

Examination of ESBL genes namely SHV, TEM and CTX-M was carried out by PCR. The broiler chicken meat containing SHV, TEM, and CTX-M gene are 1, 18, and 24 respectively and there are 15 broiler chicken meat containing TEM + CTX-M gene. A research in Germany in 399 chicken meat samples shows as many as 185 confirmed ESBL isolates with 175 (43.9\%) samples positive. The majority of isolates were Escherichia coli 


\section{STRADA Jurnal Ilmiah Kesehatan}

DOI: $10.30994 /$ sjik.v9i1.264

ISSN: 2252-3847 (print); 2614-350X (online)

Vol.9 No.1. May 2020. Page.12-19

which produced ESV type SHV 82, CTX-M 77 and TEM 16. There were no observable differences in the prevalence of ESBL between samples of organic and conventional chicken meat. $73.0 \%$ (Kola, 2012). Human can be exposed to genes encoding ESBL resistance through food. The SHV variant was first detected in vegetables in Switzerlandtoge with blaSHV-12. Similar results were also found in vegetables in Spain (Egea et al., 2011), salad in the Netherlands (Reuland et al., 2014) and South Korea (Kim et al., 2015).

The SHV, TEM and CTX-M genes found in broiler chicken meat in the East Surabaya traditional market carried 15 isolates positive of TEM + CTX-M gene. Dagi et al. (2015) found that $8 \%$ had the CTX-M gene and $77.4 \%$ had a combined TEM and CTX-M gene. This is because the plasmid encoding the CTX-M gene is a type of IncFII plasmid, which is a large plasmid that also codes for genes resistant to other groups of antibiotics (Rao, 2012). The CTX-M gene found in other isolates is found in plasmids which have very high transmissible plasmids so that resistance spreads very quickly and efficiently. The bacteria that express CTX-M are mostly co-resistance or multi-resistant bacteria. The TEM and SHV-forming genes are found in the motile genetic element plasmid so that they are easily spread (Livermore and Brown, 2005).

\section{CONCLUSION}

There are $33(33 \%)$ of samples of broiler chicken sold in traditional markets contain ESBL producing bacteria. ESBL 30 Escherichia coli and 3 Pseudomonas aeruginosa producing bacteria.. The most genes found are CTX-M, followed by TEM then SHV. The CTX-M gene is suspected of having the ability to spread better than the SHV and TEM genes.

\section{Acknowledgment}

Kuntaman, Budi utomo, eddy bagus, sugeng, radita, wahyu

\section{REFERENCES}

Arslan, S., \& Eyi, A. (2011). 'Antimicrobial resistance and ESBL prevalence in Escherichia coli from retail meats', Journal of Food Safety, 31(2), pp. 262-267. doi: $10.1111 / \mathrm{j} .1745$.

Dagi, H., T., Al-Dulaimi, A., A., Kus, H., Seyhan, T., Findik, D., Tuncer, I., Arslan, U. (2015). Genotype distribution of extended spectrum $\beta$-lactamase producing Escherichia coli and Klebsiella pneumoniae. Biomed Res. 26(2):235-238.

Ginés Marc Solàa, Juan José González-López,b Karla Cameron-Veas,a Nuria PiedraCarrasco,b Marta Cerdà-Cuéllar,a Lourdes Migura-Garciaa, 2015. House flies (Musca domestica) as Vectors for Extended-Spectrum $\beta$-Lactamase Producing Escherichia coli on Spanish Broiler Farms.Applied and Environmental mikrobiologi.

Graczyk, T., K., Knight, R., Gilman, R., H., Cranfield, M., R. (2001). Peran lalat tanpa biting dalam epidemiologi penyakit menular manusia . Mikroba menginfeksi . 3 : 231-235. 


\section{STRADA Jurnal Ilmiah Kesehatan}

DOI: $10.30994 /$ sjik.v9i1.264

ISSN: 2252-3847 (print); 2614-350X (online)

Vol.9 No.1. May 2020. Page.12-19

Gregova, G., Kmetova, M., Kmet, V., Venglovsky, J., Feher, A. (2012). Antibiotic resistance of Escherichia coli isolated from poultry a slaughterhouse. Ann Agric Environ Med. 19(1):75-77.

Johns, I., Verheyen, K., Good, L., Rycroft, A. (2012). Antimicrobial resistance in faecal Escherichia coli isolates from horses treated with antimicrobials: a longitudinal study in hospitalised and non-hospitalised horses. Vet Microbiol. 159:381-389.

Kola, A., Kohler, C., Pfeifer, Y., Schwab, F., Kühn, K., Schulz, K., Balau, V., Breitbach, K., Bast, A., Witte, W., Gastmeier, \& P., Steinmetz, I. (2012). High prevalence of extended-spectrum- $\beta$-lactamase-producing Enterobacteriaceae in organic and conventional retail chicken meat, Germany. J Antimicrob Chemother. 11:2631-4. doi: $10.1093 / \mathrm{jac} / \mathrm{dks} 295$.

Livermore, D., M., \& Brown, D., F., J. (2005). Detection of $\beta$-lactamase-mediated resistance. BSAC [Internet]. [diunduh 2019 juni 22]. Tersedia pada: http://bsac.org.uk/wp-content/uploads/2012/02/Chapter_6.pdf.

Lukman, D., W., Sudarwanto, M., B., Purnawarman, T., Latif, H., Pisestyani, H, Sukmawinata, E., \& Akineden, O. (2016). CTX-M-1 and CTX-M-55 producing Escherichia coli isolated from broiler feces in poultry slaughterhouses, Bogor, West Java Province. Glo Adv Res J Med Med Sci. 5(12):287-291.

Nadine, Geser, Roger, Stephan, \& Hächler, H. (2012). 'Occurrence and characteristics of extended-spectrum B-lactamase (ESBL) producing Enterobacteriaceae in food producing animals,minced meat and raw milk', BMC Veterinary Research, 8(21). Available at.

Nakayama, Tatsuya, Ueda, S., \& Huong, B., T., M. et al. (2015). Wide dissemination of extended-spectrum $\beta$-lactamase-producing Escherichia coli in community residents in the Indochinese peninsula. Dove Press Journal: Infection and Drug Resistance.

Paterson, D., L., \& Bonomo, R., A. (2005). 'Extended spectrum beta-Lactamases, clinical microbiology Reviews, 18(4), pp. 657-686.

Prendergast, L., T., B., F., Rosales, M., A., L., Evans, E., S., \& Hogsette, J., A. (2006). Filth flies. significance, surveillance and control in contingency operations. Washington: armed forces pest management board.

Rao, S. (2012). CTX-M $\beta$-lactamases. [Internet]. [diunduh 2019 Mei 22]. Tersedia pada: www.microrao.com/micronotes/pg/ctx-m-beta-lactamases.pdf.

Reich, Felix, Atanassova, V., \& Klein, G. (2013). Extended-Spectrum $\beta$-Lactamase- and AmpC-Producing Enterobacteria in healthy broiler chickens, Germany.

Ruegg, P., L. (2013). Antimicrobial residues and resistance: Understanding and managing drug usage on dairy rarms. University of WI, Dept. of Dairy Science, Madison. 


\section{STRADA Jurnal Ilmiah Kesehatan}

DOI: $10.30994 /$ sjik.v9i1.264

ISSN: 2252-3847 (print); 2614-350X (online)

Vol.9 No.1. May 2020. Page.12-19

Sana, T., Rami, K., Racha, B., Fouad, D., Marcel, A., Hassan, M., Sani, H. \& Monzer, H. (2011). Detection of genes TEM, OXA, SHV and CTX-M in 73 clinical isolates of Eschericia coli producers of extended spectrum beta-lactamase and determination of their susceptibility to antibiotics. iMedPub Journals, 1(1), pp. 1-5.

Santos, L., L., Moura, R., A., Agilar-Ramires, P., Castro, A., P., Lincopan, N. (2013). Current status of extended-spectrum $\beta$-laktamase (ESBL)-producing Enterobacteriaceae in animals. FORMATEX. 3:1600-1607.

Sarmah, A., K., Meyer, M., T., Boxall, A., B. (2006). A global perspective on the use, sales, exposure pathways, occurrence, fate and effects of veterinary antibiotics (vas) in the environment. Chemosphr.

Shaikh, N., K.,Mundhada, S., G., et al. (2016). 'comparison of different phenotypic methods for the detection of extended spectrum b-lactamase (esbl) in bacterial isolates from tertiary care centre', Int J Cur Res Rev, 8(11), pp. 10-14.

Sharma, J., Sharma, M., \& Ray, P. (2010). Detection of TEM \& SHV genes in Eschericia coli \& Klebsiella pneumoniae isolates in a Tertiary Care Hospital from India, Indian Journal Med Res, 132, pp. 332-336.

Soegiyono. (2013). Permintaan Ayam Ras Broiler Naik 15,8\% di 2013, Accessed on 21 October 2018. (http://www.livestockreview.com/2013/01/permintaan-akan-ayamras-broiler- naik-158-di-2013/).

Stuart, J., C., et al. (2012). 'Comparison of ESBL contamination in organic and conventional retail chicken meat', International Journal of Food Microbiology. Elsevier B.V., 154(3), pp. 212-214. doi: 10.1016/j.ijfoodmicro.2011.12.034.

Sudarwanto, M., Akineden, Ö., Odenthal, S., Gross, M., Usleber, E. (2015). Extendedspectrum $\beta$-lactamase (ESBL)-producing Klebsiella pneumoniae in bulk tank milk from dairy farms in Indonesia. J Food Pathog Dis. 12(7):585590.

Teixeira, P., Barreiro, C., Albano, H., \& Silva, J. (2013). Role of Flies as Vectors of Foodborne Pathogens in Rural Areas.

Tekiner, İ., H. \& Özpınar, H. (2016). 'Occurrence and characteristics of extended spectrum beta-lactamases-producing Enterobacteriaceae from foods of animal origin', Brazilian Journal of Microbiology, 47(2), pp. 444-451. doi: 10.1016/j.bjm.2015.11.034.

Tham, \& Johan. (2012). Extended spectrum $\beta$-lactamase producing Enterobacteriaceae: Epidemiology, risk factors, and duration of Carriage. Department of clinical sciences, Lund University.

Tille, Patricia, M. (2014). Diagnostic microbiologi. $13^{\text {th }}$. Mosby, Inc., an affiliate of Elsevier Inc. Riverport Lane St. Louis, Missouri 63043. 


\section{STRADA Jurnal Ilmiah Kesehatan}

DOI: $10.30994 /$ sjik.v9i1.264

ISSN: 2252-3847 (print); 2614-350X (online)

Vol.9 No.1. May 2020. Page.12-19

Widyawati, P., Wahyu, I., Soesanti. (2013). Identifikasi tingkat kesegaran daging ayam broiler berdasarkan ciri tekstur dan warna daging. Journal Al-Mabsud. Vol 6, No 1.

Yusuf, \& Zuhriana, K. (2010). Polymerase chain reaction (PCR). Saintek Vol 5, No 6. 